\title{
Inbreeding depression in single, three way and double-cross hybrids of maize
}

\author{
F.B.S. Botelho ${ }^{1}$, A.T. Bruzi ${ }^{1}$, I.P. Lima ${ }^{1}$, C.S. Rodrigues ${ }^{2}$ and \\ R.T. de C. Botelho ${ }^{3}$ \\ ${ }^{1}$ Departamento de Agricultura, Universidade Federal de Lavras, \\ Lavras, MG, Brasil \\ ${ }^{2}$ Departamento de Biologia, Universidade Federal de Lavras, \\ Lavras, MG, Brasil \\ ${ }^{3}$ Universidade Federal de Lavras, Lavras, MG, Brasil \\ Corresponding author: F.B.S. Botelho \\ E-mail: flaviabotelho@dag.ufla.br
}

Genet. Mol. Res. 15 (3): gmr.15035497

Received March 19, 2016

Accepted May 25, 2016

Published September 23, 2016

DOI http://dx.doi.org/10.4238/gmr.15035497

Copyright (C) 2016 The Authors. This is an open-access article distributed under the terms of the Creative Commons Attribution ShareAlike (CC BY-SA) 4.0 License.

\begin{abstract}
Currently, one of the acclaimed alternatives for increasing maize yield is accomplished through utilization of heterosis in hybrid cultivars. However, upon performing crosses between related pairs, there are losses due to inbreeding depression. Thus, the aim of this study was to estimate inbreeding depression and the contribution of loci in heterozygosity in different types of maize hybrids. Eight treatments were evaluated, considering the $\mathrm{F}_{1}$ and $\mathrm{S}_{0}$ generations of four commercial hybrids. A randomized block experimental design was used, with three replications, and plots consisting of two three-meter long rows at a spacing of $0.50 \mathrm{~m}$. The traits evaluated were plant height, first ear height and husked ear weight. For ear weight trait, there was a significant difference, where the treatments could be classified into three distinct groups. In this case, the single-cross hybrids AG7088
\end{abstract}


and 30F90Y exhibited greater depression through inbreeding due to the greater contribution of loci in heterozygosity and consequent predominance of deviations due to dominance.

Key words: Zea mays; Heterosis; Agronomic traits

\section{INTRODUCTION}

Since maize is one of the most highly produced grains in Brazil, emphasis should be placed on the importance of high quality seeds for good performance and genetic quality, with the least possible effect of environmental factors on plant development. Genetic breeding is one of the main tools used to obtain cultivars that are more adapted to different environmental conditions. Among the alternatives used to obtain plants with characteristics greater than the mean value of their parents is the use of heterosis (Beck et al., 1990). However, expression of heterosis depends on the differences in the allelic frequencies of the parent plants. Beck et al. (1990) affirm that, because of this, expression of heterosis is expected to be less in crosses between broad based open-pollination populations.

In the seed market, single-cross hybrid seeds stand out as the highest yielding, but high seed cost hinders their use by producers who cannot make use of more technically advanced growing practices and who use open-pollination seed varieties from their own corn cribs, and this results in low grain yield in Brazil (Ferreira et al., 2009). Low grain yield occurs because, in these cases, there is inbreeding depression, which is simply loss of vigor due to crosses between related individuals.

The greater the frequency of loci in heterozygosity is in the population, the greater the possibility is of obtaining lines with different genetic makeup in the S$\infty$ generation. In the event of dominance in the control of the target trait, as well as loci in heterozygosity, the occurrence of inbreeding depression in the population may be foreseen. In light of the above, it may be inferred that the estimation of inbreeding depression may indicate the contribution of loci in heterozygosity (d) in the population. Thus, in the comparison of two populations, as long as the contribution from the different loci is similar, the population with greater frequency of loci in heterozygosity will have greater inbreeding depression.

There are various studies that cite estimates of inbreeding depression for various characteristics using different maize populations but with common endosperm (Hallauer and Sears, 1973; Good and Hallauer, 1977; Viana et al., 1982; Lima et al., 1984; Nass and Miranda Filho, 1995; Vasal et al., 1995). Nevertheless, in addition to varying results in relation to the genotype evaluated, the studies in the literature are mostly from the 1980s and 1990s.

Thus, it is important to estimate the loss of grain yield which comes from inbreeding depression in currently recommended genotypes. Consequently, the aim of this study was to estimate inbreeding depression in different types of maize hybrids, as well as measure the contribution of loci in heterozygosity to agronomic traits.

\section{MATERIAL AND METHODS}

The study was conducted at Universidade Federal de Mato Grosso in Sinop, MT, Brazil. Mean annual rainfall in the region is $2500 \mathrm{~mm}$ with two distinct periods composed of three dry months (June, July and August) and three months of intense rain (January, February

Genetics and Molecular Research 15 (3): gmr.15035497 
and March). Climate classification is Aw, with mean annual temperature of $24^{\circ} \mathrm{C}$, ranging from $18^{\circ}$ to $40^{\circ} \mathrm{C}$. The municipality is situated at $11^{\circ} 51^{\prime} 51^{\prime \prime} \mathrm{S}, 55^{\circ} 30^{\prime} 09^{\prime \prime} \mathrm{W}$, with an altitude of $345 \mathrm{~m}$. Soil in the location where the experiments were conducted is classified as Oxisol.

The $\mathrm{F}_{1}$ and $\mathrm{S}_{0}$ generations of different types of commercial hybrids (Balu761, 30F90Y, AG7088, and 2B688) were evaluated and their main characteristics are shown in Table 1.

Table 1. Listing of hybrids and their main agronomic characteristics, Sinop, MT, Brazil, 2013.

\begin{tabular}{l|l|l}
\hline Hybrids & Origin & Agronomic characteristics \\
\hline Balu761 & Sementes Balu & $\begin{array}{l}\text { Conventional double cross hybrid; adapted to different regions; medium/high investment in technology recommended; early } \\
\text { variety with 798 degree day (DD) cycle; used for grain production and whole plant silage. }\end{array}$ \\
\hline 30F90Y & Pioneer & $\begin{array}{l}\text { Single cross transgenic hybrid; early variety with 140 day cycle; used for silage production; high yield potential; has } B t \\
\text { technology; requires medium/high investment in technology. }\end{array}$ \\
\hline AG7088 & Agroceres & $\begin{array}{l}\text { Single cross conventional hybrid; early variety with } 880 \text { DD cycle; used for grain production; requires high investment in } \\
\text { technology; adapted to regions at an altitude greater than 700 m. }\end{array}$ \\
\hline 2B688 & Dow Agrosciences & $\begin{array}{l}\text { Conventional three-way cross hybrid; early variety with } 860 \text { DD cycle; may be grown early, normal, late or as a second crop; } \\
\text { used for grain production and whole plant silage; good drought tolerance. }\end{array}$ \\
\hline
\end{tabular}

The study was conducted in two distinct steps. In the first, the $\mathrm{S}_{0}$ generation was obtained, i.e., the inbred generation; in the second step, the plants obtained by means of commercial seeds $\left(\mathrm{F}_{1}\right)$ and open-pollination seeds $\left(\mathrm{S}_{0}\right)$ were compared in regard to agronomic characteristics.

For the first step, the conventional tillage system was adopted, i.e., soil was prepared by disking, with later base fertilization, using $300 \mathrm{~kg} / \mathrm{ha} \mathrm{8-28-16} \mathrm{NPK}$. The four types of hybrids were sown in isolated fields in three three-meter rows, with a spacing of $20 \mathrm{~cm}$ between plants and $50 \mathrm{~cm}$ between rows. Side dressing fertilization was performed with the 18-0-18 NPK, and pest control was performed through application of the organophosphate chlorpyrifos, the pyrethroid imidacloprid and the benzoylurea teflubenzuron. Weeds were manually removed. When plants reached physiological maturity, the ears were harvested manually. The ears were husked and shelled, and the $\mathrm{S}_{0}$ seeds were stored at $13 \%$ moisture.

For the second step, a conventional tillage system was also adopted, as in the previous experiment. A randomized block design was used, with eight treatments obtained with four distinct cultivars (Balu761, 30F90Y, AG7088, and 2B688) in the $\mathrm{F}_{1}$ and $\mathrm{S}_{0}$ generations. Three replications and plots of two three-meter rows were used, with between-row spacing of $50 \mathrm{~cm}$, and sowing density of four seeds per linear meter. Crop treatments were the same as performed in the first step of the study.

The characteristics evaluated were: a) plant height: distance from the soil surface to the collar of the flag leaf, using a measuring stick, on five plants from the plot at random; b) first ear height: distance from the soil surface to the base of the first ear, using a measuring stick, on five plants from the plot at random; c) husked ear weight: the ears collected from each plot were weighed on a graduated scale.

After obtaining the data, analysis of variance was performed, considering each trait separately by means of the SAS Institute (2002) statistical program. The performance of the different hybrids in relation to the traits evaluated was compared using the Scott and Knott (1974) mean comparison test at 5\% probability. For evaluation of experimental precision, the accuracy estimate was adopted (Resende and Duarte, 2007).

Inbreeding depressions of each hybrid evaluated were estimated considering each trait by means of the following estimator: $\mathrm{ID}=\left[\left(\mathrm{F}_{1}-\mathrm{S}_{0}\right) / \mathrm{F}_{1}\right] \times 100$, in which: ID $=$ inbreeding depression; $\mathrm{F}_{1}=$ mean value of the $\mathrm{F}_{1}$ generation; and $\mathrm{S}_{0}=$ mean value of the $\mathrm{S}_{0}$ generation. The contribution of the loci in heterozygosity was also estimated, using the following expression: 
$\delta=2\left(\mathrm{~F}_{1}-\mathrm{S}_{0}\right)$, in which: $\delta=$ loci in heterozygosity; $\mathrm{F}_{1}=$ mean value of the $\mathrm{F}_{1}$ generation; and $\mathrm{S}_{0}=$ mean value of the $\mathrm{S}_{0}$ generation (Lima et al., 1984).

\section{RESULTS AND DISCUSSION}

Accuracy was the parameter used to estimate experimental precision. According to Table 2, the experiments exhibited high accuracy estimates, ranging from 70.5 to $97.0 \%$, considering the traits of plant height and husked ear weight, respectively, According to Resende and Duarte (2007), accuracy estimates greater than 70\% indicate good evaluation quality of the experiments.

Table 2. Mean values of plant height and distance from soil surface to base of first ear in meters, and husked ear weight in grams considering the $\mathrm{F}_{1}$ and $\mathrm{S}_{0}$ generations of the 4 hybrids evaluated. UFMT, Sinop, MT, Brazil, 2013.

\begin{tabular}{|c|c|c|c|}
\hline \multirow[t]{2}{*}{ Treatments } & \multicolumn{3}{|c|}{ Characteristics } \\
\hline & Plant height $(\mathrm{m})$ & Distance from soil surface to base of first ear $(\mathrm{m})^{1}$ & Husked ear weight $(\mathrm{g})^{1}$ \\
\hline 2B688 ( $\left.\mathrm{F}_{1}\right)$ & 1.41 & 0.43 & $580.90^{\mathrm{b}}$ \\
\hline $\mathrm{AG7088( \textrm {F } _ { 1 } )}$ & 1.40 & 0.45 & $973.15^{\mathrm{a}}$ \\
\hline $30 \mathrm{~F} 90 \mathrm{Y}\left(\mathrm{F}_{1}\right)$ & 1.66 & 0.47 & $927.15^{\mathrm{a}}$ \\
\hline Balu761 $\left(\mathrm{F}_{1}\right)$ & 1.46 & 0.46 & $397.00^{\mathrm{b}}$ \\
\hline 2B688 ( $\mathrm{S}_{0}$ seeds) & 1.35 & 0.42 & $295.70^{\mathrm{c}}$ \\
\hline AG7088 ( $\mathrm{S}_{0}$ seeds) & 1.32 & 0.41 & $163.10^{\mathrm{c}}$ \\
\hline 30F90Y ( $\mathrm{S}_{0}$ seeds) & 1.62 & 0.50 & $269.25^{\mathrm{c}}$ \\
\hline Balu761 ( $\mathrm{S}_{0}$ seeds) & 1.38 & 0.40 & $477.50^{\mathrm{b}}$ \\
\hline Accuracy $(\%)$ & 70.5 & 90.5 & 97.0 \\
\hline General mean value & 1.45 & 0.44 & 510.47 \\
\hline
\end{tabular}

${ }^{1}$ Mean values followed by the same letter belong to the same group according to the Scott and Knott (1974) test $(\mathrm{P}<0.05)$.

Significant differences were detected between the treatments for the husked ear weight trait. It should be emphasized that the commercial hybrids stood out in relation to the inbred generation (Table 2). Farias Neto and Miranda Filho (2000) showed in their study that plants coming from $\mathrm{S}_{0}$ seeds (originating from self-pollination) exhibit greater depression in characteristics controlled by greater levels of dominance. As the maize plant is an allogamous species, it is favored by the genetic diversity of its parents; thus, the heterosis levels rise in accordance with greater diversity. For the characteristic of husked ear weight, this gain was more evident in the $F_{1}$ seeds, and decrease in yield brought about by inbreeding depression was observed in the $\mathrm{S}_{0}$ generation.

In the ear weight trait, which represents grain yield strictly speaking, the expression of heterosis and losses through inbreeding depression are more evident due to the genetic complexity involved in control of the characteristic in question (Table 2).

As observed in Table 2, the hybrids AG7088 $\left(\mathrm{F}_{1}\right)$ and 30F90Y $\left(\mathrm{F}_{1}\right)$ stood out, for they yielded the greatest mean values. The cultivars 2B688 $\left(\mathrm{F}_{1}\right)$, Balu761 $\left(\mathrm{F}_{1}\right)$ and Balu761 (seeds from the corn crib) were in the second group. In this case, the mean values were intermediate, and there was no statistical difference between them. It may be noted that the plants coming from $F_{1}$ seeds and corn crib seeds of the cultivar Balu761 showed statistically equivalent ear weights. That may be explained by the great stability and adaptation capacity of the doublecross hybrid, acquired from an extensive genetic base, which single-cross hybrids do not have. The cultivars 2B688 (corn crib seeds), AG7088 (corn crib seeds) and 30F90Y (corn crib seeds) were in the third group, which did not statistically differ between themselves and had the lowest mean yield values of the hybrids evaluated.

Genetics and Molecular Research 15 (3): gmr.15035497 
Considering the estimates of inbreeding depression and contribution of loci in heterozygosity, shown in Table 3, it was seen that for the characteristics of plant height and distance from the soil surface to the base of the first ear, the estimates of inbreeding depression were of lower magnitude when compared to the estimates for the ear weight trait.

Table 3. Estimate of inbreeding depression (ID) and contribution of the loci in heterozygosity $(\delta)$ of the hybrids evaluated. UFMT, Sinop, MT, Brazil, 2013.

\begin{tabular}{|c|c|c|c|c|c|c|}
\hline \multirow{2}{*}{ Hybrids } & \multicolumn{2}{|c|}{ Plant height } & \multicolumn{2}{|c|}{ Distance from soil surface to base of first ear } & \multicolumn{2}{|c|}{ Husked ear weight } \\
\hline & ID (\%) & $\delta(\mathrm{m})$ & ID (\%) & $\delta(\mathrm{m})$ & ID (\%) & $\delta(\mathrm{g})$ \\
\hline 2B688 & 4.25 & 0.12 & 2.32 & 0.02 & 49.09 & 570.40 \\
\hline AG7088 & 5.71 & 0.16 & 8.88 & 0.08 & 83.24 & 1620.10 \\
\hline $30 \mathrm{~F} 90 \mathrm{Y}$ & 2.40 & 0.08 & -6.38 & -0.06 & 70.96 & 1325.80 \\
\hline Balu761 & 8.00 & 0.14 & 10.87 & 0.10 & -20.28 & -161.00 \\
\hline
\end{tabular}

In the literature, it is frequently stated that the estimate of inbreeding depression is a function of the contribution of the loci in dominance in expression of the trait. This fact was observed in this study (Table 3). Notice that the traits of plant height and distance from the soil surface to the base of the first ear showed less inbreeding depression. Characteristics such as plant height and distance from the soil surface to the base of the first ear are controlled by few genes, which may explain the lower inbreeding depression. Evgenidis et al. (2001) demonstrated that the contribution of the loci in heterozygosity for yield characteristics was greater than that of loci in homozygosity, whereas in relation to plant height and distance from the soil surface to the base of the first ear, the loci in homozygosity made a greater contribution.

In the study of Maldonado and Miranda Filho (2002), inbreeding depression for the plant height trait was from 1.0 to $12 \%$, very near the values we obtained, which varied from 2.40 to $8.00 \%$ for the cultivars $30 \mathrm{~F} 90 \mathrm{Y}$ and Balu761, respectively. Inbreeding depression in the trait of distance from the soil surface to the base of the first ear was also low, ranging from $-6.38 \%$ for $30 \mathrm{~F} 90 \mathrm{Y}$ to $10.87 \%$ for Balu 761 . Negative values for inbreeding depression may indicate a large number of loci in homozygosity, which maintains genetic stability of the cultivar and leads to less depreciation of the characteristics in question.

As for the ear weight trait, inbreeding depression reached values of high magnitude, with a minimum value of $-20.28 \%$ for Balu 761 , and a maximum value of $83.24 \%$ for AG7088. Other studies estimated inbreeding depression for the ear weight trait and found values that were not very consistent, values much lower or intermediate in relation to the values found in this study. Studies such as those of Maldonado and Miranda Filho (2002) with maize showed that inbreeding depression in the plant height and ear height traits is not expressed as much as in grain yield. This is due to greater genetic complexity, showing that such a characteristic does not have complex dominance as much as characteristics inherent to yield.

In the study of Farias Neto and Miranda Filho (2000), for example, the values of inbreeding depression were -10.1 and $-11.3 \%$. Maldonado and Miranda Filho (2002) evaluated two generations in three populations and obtained values from -14 to $-4.1 \%$.

Another parameter evaluated was the contribution of the loci in heterozyosity $(\delta)$. Miranda Filho (1999) affirms that $\delta$ depends on the divergence between the lines and the existence of dominance in the control of the trait. Thus, to obtain good hybrids, it is necessary that progeny have good performance and that they should be divergent. In this study, the

Genetics and Molecular Research 15 (3): gmr.15035497 
estimate of $\delta$, considering the characteristics of plant height and distance from the soil surface to the base of the first ear, was low, indicating little contribution from heterosis. For the first trait, the contribution from the loci in heterozygosity ranged from $0.08 \mathrm{~m}$ for the cultivar 30F90Y, to $0.16 \mathrm{~m}$ for the hybrid AG7088. Farias Neto and Miranda Filho (2000) obtained a value of $0.62 \mathrm{~m}$ for the plant height trait and $0.56 \mathrm{~m}$ for loci in heterozygosity. Maldonado and Miranda Filho (2002) estimated values that ranged from 0.112 to $0.758 \mathrm{~m}$ for the same trait.

For the first ear height trait, the $\delta$ values were low, also indicating little genetic variation. The values obtained were $-0.06 \mathrm{~m}$ for $30 \mathrm{~F} 90 \mathrm{Y}, 0.02 \mathrm{~m}$ for 2B688, $0.08 \mathrm{~m}$ for AG7088 and $0.1 \mathrm{~m}$ for Balu761. In the previously cited studies, the estimate of loci in heterozygosity was similar, as in Evgenidis et al. (2001).

The estimate of loci in heterozygosity for the ear weight trait was high, as was already expected, due to the participation of many genes controlling the characteristic. This implies greater variability and, consequently, greater participation of heterosis in the results. The values obtained for the characteristic were $-161 \mathrm{~g}$ for Balu761, 570.4 $\mathrm{g}$ for 2B688, $1315.8 \mathrm{~g}$ for 30F90Y and $1620.1 \mathrm{~g}$ for AG7088.

Considering 2B688, inbreeding depression for the ear weight trait was $49.09 \%$. The greatest discrepancy between mean values of the generations evaluated was for AG7088, in which the mean value of ear weight for plants coming from commercial seeds was around $83.23 \%$ greater than that of plants coming from seeds from the corn crib.

The transgenic single-cross hybrid 30F90Y also exhibited a large difference, where the plants derived from corn crib seeds had a yield performance approximately $71 \%$ below that of plants obtained from $\mathrm{F}_{1}$ seeds. As mentioned above, Balu761 did not show statistical difference in mean ear weight of plants from $\mathrm{F}_{1}$ versus those from corn crib seeds.

Single-cross hybrids are derived from two lines; i.e., there is a narrow genetic base and there is less possibility of gene complementation. Therefore, significant effects from interaction between single-cross hybrids and locations are frequently seen since the narrow genetic base of these hybrids allows a more differentiated response in regard to locations of evaluation than in the case of double-cross hybrids and cultivars of a broader genetic base (Hallauer et al., 2010). These effects mean greater losses for single-cross hybrids than for double-cross hybrids, which have less hybrid vigor but greater capacity for adaptation and less loss through inbreeding. Double-cross hybrids have a smaller number of loci in heterozygosity, responsible for deviations of dominance (not inheritable), which provided for greater stability when compared to single-cross hybrids.

It was possible to observe the occurrence of inbreeding depression for the husked ear weight trait. That did not occur for the plant height and first ear height characteristics. For the husked ear weight characteristic, the hybrid that showed the least loss of vigor was the conventional double-cross hybrid Balu761, whereas the hybrid that showed the greatest inbreeding depression was the conventional single-cross hybrid AG7088.

\section{CONCLUSIONS}

With the estimate of the contribution of the loci in heterozygosity, the predominance of deviations due to dominance was observed for all the characteristics evaluated. Therefore, for the maize crop, the ideal situation is for the producer to make use of commercial genetic seeds. The greatest inbreeding depression was observed in the conventional single-cross hybrid.

Genetics and Molecular Research 15 (3): gmr.15035497 


\section{ACKNOWLEDGMENTS}

The authors thank Universidade Federal de Mato Grosso, Sinop Campus, for assistance in conducting this study.

\section{REFERENCES}

Beck DL, Vasal SK and Crossa J (1990). Heterosis and combining ability of CIMMYT's tropical early and intermediate maturity maize (Zea mays L.) germplasm. Maydica 35: 279-285.

Evgenidis G, Fotiadis N, Georgiadis S, Ligos E, et al. (2001). Analysis of diallel crosses among CIMMYT's subtropicaltemperate and adapted to the US Corn Belt maize populations. Maydica 46: 47-52.

Farias Neto AL and Miranda Filho JB (2000). Inbreeding in two maize subpopulations selected for tassel size. Sci. Agric. 57: 487-490. http://dx.doi.org/10.1590/S0103-90162000000300018

Ferreira EA, Paterniani MEAGZ, Duarte AP, Gallo PB, et al. (2009). Performance of maize top cross hybrids from S3 lines in three environments in São Paulo State. Bragantia 68: 319-327. http://dx.doi.org/10.1590/S0006$\underline{87052009000200005}$

Good RL and Hallauer AR (1977). Inbreeding depression in maize by selfing and full-sibbing. Crop Sci. 17: 935-940. http://dx.doi.org/10.2135/cropsci1977.0011183X001700060030x

Hallauer AR and Sears JH (1973). Changes in quantitative traits associated with inbreeding in a synthetic variety of maize. Crop Sci. 13: 327-330. http://dx.doi.org/10.2135/cropsci1973.0011183X001300030012x

Hallauer AR, Carena MJ and Miranda Filho JD (2010). Quantitative genetics in maize breeding. Springer

Lima M, Miranda Filho JB and Gallo PB (1984). Inbreeding depression in Brazilian populations of maize (Zea mays L.). Maydica 29: 203-215.

Maldonado FAA and Miranda Filho JB (2002). Inbreeding depression in maize populations of reduced size. Sci. Agric. 59: 335-340. http://dx.doi.org/10.1590/S0103-90162002000200020

Miranda Filho JB (1999). Inbreeding and heterosis, pp 69-80. In: The genetics and exploitation of heterosis in crops. Coors JG, Pandey S. eds. Madison, ASA.

Nass LL and Miranda Filho JB (1995). Inbreeding depression rates of semi-exotic maize (Zea mays L) populations. Rev. Bras. Genet. 18: 585-592.

Resende MDV and Duarte JB (2007). Precisão e controle de qualidade em experimentos de avaliação de cultivares. Pesqui. Agropecu. Trop. 37: 182-194.

SAS Institute (2000). SAS/STAT User's Guide, Version 8. Cary.

Scott AJ and Knott M (1974). Accouter analysis methods for grouping means in the analysis of variants. Biometrics 30 : 507-512. http://dx.doi.org/10.2307/2529204

Vasal SK, Dhillon BS, Srinivasan G, Mclean SD, et al. (1995). Effect of S3 recurrent selection in four tropical maize populations on their selfed and randomly mated generations. Crop Sci. 35: 697-702. http://dx.doi.org/10.2135/crops ci1995.0011183X003500030008x

Vianna RT, Gama EEG, Naspolini Filho V, Moro JR, et al. (1982). Inbreeding depression of several introduced populations of maize (Zea mays L.). Maydica 27: 151-157.

Genetics and Molecular Research 15 (3): gmr.15035497 